\title{
Cattle and Salmon II: Interactions Between Cattle and Spawning Spring Chinook Salmon (Oncorhynchus tshawytscha) in a Northeastern Oregon Riparian Ecosystem
}

\author{
Teena M. Ballard ${ }^{1}$ and William C. Krueger ${ }^{2}$ \\ Authors are ${ }^{1}$ Hydrologist, USDA Forest Service, La Grande Ranger District, 3502 Hwy 30, La Grande, OR 97850; and \\ ${ }^{2}$ Professor, Department of Rangeland Resources, Oregon State University, Corvallis, OR 97331.
}

\begin{abstract}
The study addressed the interaction between cattle and spawning spring chinook salmon late in the summer, when it is common for cattle to be present in pastures that have streams where spawning occurs. We addressed the occurrence of spawning in the study area and 2 potential impacts of cattle behavior during chinook salmon spawning: 1) disruption of spawning behavior by the presence of cattle near the redd and 2) the frequency of actual cattle contact with redds. Frequency of salmon redds was not significantly different in the stream reaches accessible to cattle compared with excluded reaches. Salmon continued preexisting patterns of behavior while cattle were within visible range of a redd. Cattle were seldom close to a redd and the chance for direct interaction to occur was minimal. When cattle were visibly near the active redd, cattle remained greater than $3.0 \mathrm{~m}$ from the active redd $84 \%$ of the time. Of the total time redds were observed, cattle contacted the redds $<0.01 \%$ of the time. Previous studies have shown salmon that are harassed during spawning can retain eggs and even go completely unspawned. All salmon fully spawned in the study area in both years of the study.
\end{abstract}

\section{Resumen}

Este estudio aborda la interacción entre el ganado y la ovoposición del "Spring chinook salmon" a fines del verano, cuando es común que el ganado este presente en los potreros que tienen corrientes de agua donde ocurre la ovoposición de esta especie. Estudiamos la ocurrencia de la ovoposición en el área de estudio y dos impactos potenciales del comportamiento del ganado durante la ovoposición del salmón: 1) La interrupción de la ovoposición por la presencia del ganado en las áreas activas de ovoposición (nidos) y 2) la frecuencia del contacto del ganado con los nidos. La frecuencia de los nidos del salmón no fue significativamente diferente en los bancos de las corrientes accesibles al ganado a las de los bancos restringidos a el. El salmón continuó con sus patrones de comportamiento pre-existentes aunque el ganado estuviera en un rango visible de un nido. El ganado rara vez estuvo cerca de un nido y la posibilidad de que ocurriera un contacto directo fue mínima. Cuando el ganado estuvo visiblemente cerca de un nido activo de salomón, el $84 \%$ del tiempo permaneció a más de $3.0 \mathrm{~m}$ de distancia de él. Del tiempo total de observación del los nidos, el ganado los contacto menos de $0.01 \%$ del tiempo. Estudios previos han mostrado que los salmones que son acosados durante la ovoposición pueden retener los huevos y aun marcharse sin haber ovopositado. En el área de estudio todos los salmones ovopositaron plenamente en ambos años.

Key Words: behavior, salmon redd, environmental impact, endangered species

\section{INTRODUCTION}

Little is known of the interactions that take place between freeroaming cattle and spawning spring chinook salmon (Onchorhynchus tshawytscha), a threatened and endangered fish species in the Pacific Northwest. To date, most research has been on the effects of cattle on fish habitat and has focused on impacts to vegetation, soils, and nutrient cycling (Krueger 1996), with little focus on direct or behavioral impacts by cattle on salmon.

Grazing, resting, and shelter-seeking activities typically dominate free-roaming cattle behavior. Drinking is the prin-

Research was funded by the Oregon Agricultural Experiment Station, Technical paper 11901.

At the time of research, Ballard was research assistant, Oregon State University, Eastern Oregon Agricultural Research Center, Union, OR 97883.

Correspondence: Teena M. Ballard, USDA Forest Service, La Grande Ranger District, 3502 Hwy 30, La Grande, OR 97850. Email: tballard@fs.fed.us

Manuscript received 31 May 2002; manuscript accepted 14 November 2004. cipal activity when they are in direct contact with a water body (Arnold 1981). Cattle tend to drink 1.5 times per day, spending 3-26, or greater, minutes per drinking period, depending on temperature, humidity, and moisture content of the feed (Wagnon 1963; Sneva 1970; McInnis 1985). So streams naturally attract cattle at least 1 or 2 times per day. Cattle can directly impact water bodies through activities such as walking through the water. So there is concern that cattle in riparian areas can negatively impact spawning activities and, consequently, productivity of salmon populations.

A national management priority in natural resources is to enhance native salmonid populations in the Pacific Northwest. Chinook salmon that spawn in the headwaters of the Blue Mountains have been classified as a stream type (Gilbert 1913). Returning adult salmon enter these fresh waters in the spring and spend several months in the headwaters before spawning. Cattle graze the adjoining riparian and upland communities and frequent these same water bodies. 
We evaluated the selection of spawning sites with reference to presence or absence of cattle grazing and addressed two potential interactions between cattle and spawning activities of spring chinook salmon: 1) disruption of spawning activity behavior because of the proximity of cattle to spawning salmon and 2) spawning habitat utilization by salmon and cattle. Spawning activity is used as a general description of the suite of activities salmon exhibit from the time they initiate building a redd until they die. The actual act of spawning is a very short period, during which eggs are deposited in a redd and fertilized. The term spawning is used in this context.

\section{METHODS AND MATERIALS}

\section{Study Area}

The study area was located in the Blue Mountain Ecological Province (Anderson et al. 1998) $15 \mathrm{~km}$ southeast of Union, Oregon, in the southwestern foothills of the Wallowa mountains on the Eastern Oregon Agricultural Research Center (EOARC). The study area consisted of a long, narrow pasture, approximately 41 hectares in size, located in a valley bottom at about $1018 \mathrm{~m}$ elevation along $2.6 \mathrm{~km}$ of Catherine Creek. The stream was at lat $45^{\circ} 7^{\prime} 57^{\prime \prime} \mathrm{N}$, long $117^{\circ} 42^{\prime} 31^{\prime \prime} \mathrm{W}$.

Catherine Creek is a third-order tributary of the Grande Ronde River, which eventually drains into the Columbia River system. The yearly mean discharge for Catherine Creek at the study location during the study was $2.12 \mathrm{~m}^{3} \cdot \mathrm{s}^{-1}$ in 1996 and $3.37 \mathrm{~m}^{3} \cdot \mathrm{s}^{-1}$ in 1997, with peak flows in June for 1996 and in May for 1997 (US Geological Survey 1996, 1997). The average maximum air temperatures for August and September were $26^{\circ} \mathrm{C}$ in 1996 and $27^{\circ} \mathrm{C}$ in 1997 (Oregon Climate Service 1998).

The Catherine Creek study area is located within an Oregon Department of Fish and Wildlife (ODFW) index area that is surveyed 3 times each year for spring chinook salmon spawning, redd abundance, and percent of eggs spawned. The area is also part of a larger index area that is surveyed once a year to determine the total number of redds and percent of eggs spawned for the entire Catherine Creek drainage. Catherine Creek is an important area for chinook salmon, and the study area is a key spawning location.

The vegetation in the study area provides a mosaic of plant habitats. The study area vegetation was mapped within a 50meter-wide strip on each side of the stream (Kauffman et al. 1985). The habitats identified ranged from meadow habitats dominated by Kentucky bluegrass (Poa pratensis L.), disturbance habitats dominated by cheatgrass (Bromus tectorum L.), to tree-dominated habitats containing one or more of the following: ponderosa pine (Pinus ponderosa Dougl.), grand fir (Abies grandis (Dougl.) Forbes), or black cottonwood (Populus trichocarpa T. \& G.). The area adjacent to the stream also included low-shrub habitats dominated by snowberry (Symphoricarpos albus (L.) Blake), tall-shrub habitats dominated by thin leaf alder (Alnus incana (L.) Moench) or black hawthorn (Crataegus douglasii Lindl.), and the gravel bars dominated by willow (Salix L. spp.).

\section{Salmon Spawning Redd Designation and Grazing Strategy}

Periodic observations were made along the study area of Catherine Creek in early August to detect the onset of spring chinook salmon spawning activity. The grazing study began each year once salmon were observed actively developing a redd, then cattle were stocked into the study area. The stocking rate for both 1996 and 1997 was 0.82 ha $\cdot \mathrm{AUM}^{-1}$. In 1978, 5 cattle exclosures were constructed alternating with grazed portions of the riparian area. The exclosures covered approximately $50 \%$ of the riparian area within $50 \mathrm{~m}$ of the stream. In 1996 and 1997, 40 cow/calf pairs were placed in the study area for the first 14 days and then 20 additional cow/calf pairs were put in the study area for the last 14 days. This stocking rate, for the available pasture not excluded from grazing, is near the maximum cattle density that would be encountered on a nonirrigated northeastern Oregon grazed meadow. This equaled approximately 50 cattle grazing for 28 days for both years of the study.

Water for the cattle is provided by Catherine Creek throughout the pasture and salt is provided ad libitum at one area in the pasture. No efforts were made to influence the distribution and utilization patterns of the cattle within the study area. The cattle were moved to another pasture after the Kentucky bluegrass was utilized about $60 \%-70 \%$ by weight.

The presence of redds was monitored daily and the locations recorded on an overlay of an aerial photograph of the study area. The first redd accessible to cattle and active with a salmon in the prespawning stage was chosen for observation. This redd was observed until the female salmon died and another redd was randomly selected for observation until the female in each subsequent redd died. There were a total of 3 different redds observed each year of the study.

\section{Salmon Spawning Activity Designation}

Ten salmon activities were identified based on 4 years of prior observation of spawning activities of salmon in the study area. The 10 activities consisted of the following: spawning, working the redd (includes digging, fanning, burying eggs, and fluffing or working on the redd), swimming around the redd, hiding under cover, resting in the redd, darting to cover, protecting the redd, fighting with males, absent from area, and missing data.

An active salmon redd was randomly chosen for observation if it met 2 criteria: 1) the salmon in the redd was in the beginning stages of building the redd and 2) the redd was in the area accessible to cattle. Once a redd was chosen for observation, the activities of the female salmon occupying the redd were recorded for 2 out of 3 randomly selected 4-hour periods per day $(0700-1059,1100-1459,1500-1859)$ each of 15 days in 1996 and 12 days in 1997. Data were not collected at night because the fish were not visible then. Activities were recorded for each second during each period sampled.

The observer was positioned $5-10 \mathrm{~m}$ from a redd with a good view of the pasture and the redd. The observer was located in a natural blind that provided full visibility of the redd, so the observers presence would not influence fish or cattle behavior. When cattle became visible to the observer of the redd, the observer would monitor the cow closest to the redd and record how much time and what type of activity the cow was doing at designated distances around the redd. The observer would also continue to record the fish activity while the cattle were present and record any other notable behavior by the fish that might be related to the presence of the cattle. 
Table 1. The distribution of spring chinook salmon redds in areas accessible compared with areas inaccessible to cattle from 1993 through 1997. Only the 1996 and 1997 comparison of redds in areas accessible versus those inaccessible to cattle were tested statistically, and they were not significantly different.

\begin{tabular}{lcc}
\hline & \multicolumn{2}{c}{ Number of Redds } \\
\cline { 2 - 3 } Year & Inaccessible & Accessible \\
\hline 1993 & 7 & 17 \\
1994 & 0 & 2 \\
1995 & 0 & 5 \\
Interactions of Cattle and Salmon in Years Studied & \\
1996 & 2 & 6 \\
1997 & 5 & 8 \\
\hline
\end{tabular}

\section{Salmon and Cattle Interactions}

Visual observations were used to measure how much time cattle were present. When cattle became visible, the cow closest to the redd was monitored for duration and type of activity, at the following ocular estimated distances: 1 ) in the redd, 2) the edge of the redd to $0.2 \mathrm{~m}, 3) 0.2-1.5 \mathrm{~m}, 4) 1.5-3.0 \mathrm{~m}$, and 5) $>3.0 \mathrm{~m}$ to where the cattle were out of sight to the observer of the redd. Redds were observed during the same 18 days cattle were observed. Cattle contact with redds was recorded when it occurred and expressed as percentage of the total time of observation.

\section{Data Analysis}

Distribution of redds in grazed and ungrazed parts of the pasture were compared with a binomial test to determine if a salmon was equally likely to choose a grazed or ungrazed area to place the redd. All other measurements were based on times activities were conducted. These were collected in seconds and averaged in minutes for analysis and reporting. Distribution of activities within years, times spent working and spawning, and distances between cows and redds were used as descriptive information and were not statistically analyzed. Comparison of salmon activities when cattle were present or absent was done with a weighted analysis of variance with redds used as blocks. The weighting was by the total number of minutes observed when cattle were either present or absent. Differences at $P \leq$ 0.05 were accepted as significant unless otherwise indicated.

\section{RESULTS AND DISCUSSION}

\section{Spawning Redd Location}

There were 8 redds in the study area in 1996 and 13 in 1997 (Table 1). Distribution of spring chinook salmon redds was not
Table 2. The percentage of time spring chinook salmon spent on activities during the 1996 and 1997 spawning seasons in the Catherine Creek study area.

\begin{tabular}{lcc}
\hline Salmon Activity & $\begin{array}{c}1996 \\
\text { \% of Time }\end{array}$ & $\begin{array}{c}1997 \\
\% \text { of Time }\end{array}$ \\
\hline Spawning & 0.54 & 0.88 \\
Working & 7.52 & 8.32 \\
Swimming Around Redd & 10.13 & 9.31 \\
Under Cover & 40.43 & 18.97 \\
Resting in Redd & 40.98 & 49.09 \\
Darting to Cover & 0.18 & 0.11 \\
Protecting the Redd & 0.22 & 0.18 \\
Absent From Redd & 0.00 & 13.14 \\
\hline
\end{tabular}

significantly different in the areas accessible to cattle compared with the excluded areas. In 1996, when there were 4.0 redds $\cdot \mathrm{km}^{-1}, 75 \%$ of the salmon spawned in areas accessible to cattle and $25 \%$ spawned in areas where cattle were excluded. In 1997 , when there were 6.1 redds $\cdot \mathrm{km}^{-1}, 63 \%$ of the salmon spawned in areas accessible to cattle and $37 \%$ spawned where cattle were excluded. This distribution of spawning sites was similar to those in the 3 years prior to this study that were sampled under the same protocol used in this study (Table 1). Visual observations of the stream did not suggest there were differences in availability of suitable spawning habitat between grazed and ungrazed areas. Because salmon appeared to select spawning sites within the areas accessible to cattle over areas where cattle were excluded, it was apparent that cattle grazing was not a deterrent to salmon spawning activity. However, because we could not discern clear spawning habitat differences between grazed and excluded areas, we could not determine why the salmon appeared to select the grazed areas for spawning.

\section{Spawning Activity}

Spawning activities of salmon were not equally distributed; resting in the redd and under cover were the dominant activities and spawning was one of the least frequent activities (Table 2). The majority (92\%) of salmon's spawning activity and $74 \%$ of salmon's working (building redds and burying eggs) activity occurred within the first 2 days of a salmon occupying each redd site (Table 3). After spawning was completed, the majority of the time was spent resting on the redd or nearby under cover.

\section{Salmon and Cattle Interaction}

Cattle were visibly present $12 \%$ of the time salmon redds were being observed. Cattle around the redds were not evenly distributed among designated distances from the redd. While

Table 3. Total minutes and percentage of time salmon spent on spawning and working (building the redd and burying eggs) activities combined in the first 2 days occupying each redd versus the remaining days occupying each redd in 1996 and 1997.

\begin{tabular}{|c|c|c|c|c|c|c|c|c|}
\hline \multirow[b]{2}{*}{ Period } & \multicolumn{3}{|c|}{1996} & \multicolumn{3}{|c|}{1997} & \multicolumn{2}{|c|}{1996 and 1997} \\
\hline & $\begin{array}{l}\text { Spawning } \\
\text { (min) }\end{array}$ & $\begin{array}{c}\text { Working } \\
\text { (min) }\end{array}$ & $\begin{array}{l}\text { Total } \\
\text { (min) }\end{array}$ & $\begin{array}{l}\text { Spawning } \\
\text { (min) }\end{array}$ & $\begin{array}{c}\text { Working } \\
\text { (min) }\end{array}$ & $\begin{array}{l}\text { Total } \\
\text { (min) }\end{array}$ & $\begin{array}{c}\text { Spawning } \\
(\%)\end{array}$ & $\begin{array}{c}\text { Working } \\
(\%)\end{array}$ \\
\hline First 2 Days & 31 & 385 & 416 & 45 & 312 & 357 & 92 & 74 \\
\hline Remaining Days & 6 & 128 & 134 & 1 & 123 & 124 & 8 & 26 \\
\hline
\end{tabular}


Table 4. The percentage of time cattle, while visible to a human observer, occupied each estimated designated distance around the redd being observed.

\begin{tabular}{lccc}
\hline Cattle Distance $(\mathrm{m})$ & $\begin{array}{c}1996 \\
\% \text { of Time }\end{array}$ & $\begin{array}{c}1997 \\
\text { \% of Time }\end{array}$ & $\begin{array}{c}1996 \text { and } 1997 \\
\% \text { of Time }\end{array}$ \\
\hline$>3.0$ & 95.60 & 72.28 & 83.93 \\
$3.0-1.5$ & 3.25 & 7.92 & 5.58 \\
$1.5-0.2$ & 0.67 & 14.91 & 7.43 \\
$0.2-0$ (Edge of the Redd) & 0.50 & 5.60 & 3.06 \\
In the Redd & 0.01 & 0.00 & $<0.01$ \\
\hline
\end{tabular}

present, cattle spent the greatest amount of time $(84 \%)$ greater than $3 \mathrm{~m}$ from the redd and the least amount of time in contact with the redd (Table 4). During the 2 years of observation of the redds, a redd was stepped on two different times. This resulted in a total of two hooves of contact with the entire redd. This was $<0.01 \%$ of the time cattle were present that cattle contacted redds. Salmon typically lay 4-6 pockets of eggs within a redd, an area roughly $3 \mathrm{~m} \times 2 \mathrm{~m}$ in size. The distribution of egg pockets within the redd in combination with the fact that the cattle spent $<1.0 \%$ of their time in the stream and $<0.01 \%$ of their time in contact with a salmon redd suggest that the likelihood of a cow stepping on a redd is very small and the chance of the cow causing significant damage to the buried eggs is also very small.

When cattle came into view of the observer, salmon maintained their preexisting pattern of behavior (Table 5). There was no significant difference in relative activities of salmon whether or not cattle were present, such as spawning when cattle were present or spawning when cattle were not present. In the presence of cattle, the dominant salmon activities were to remain at rest in the redd $(52 \%)$ or under cover $(35 \%)$. Darting, considered to be a state of agitation, occurred only twice during the 2-year study. When cattle would get close enough to a redd for the salmon to see the cow or the shadow of the cow, the fish would either move to the opposite side of the redd from the cow and continue what it was doing or the fish would drift under cover and stay there for 3-5 minutes and then come back out and resume what it was doing whether the cow remained or left. Each darting event occurred when cattle were greater than $1.5 \mathrm{~m}$ from the redd and lasted less than 2 seconds when the fish resumed the predarting activity. The rare encounters observed between cattle and salmon suggested no significant salmon stress from interactions with cattle.

Substantial stress may cause egg retention in salmon. Females that die in the spawning grounds without spawning all their eggs are considered a significant loss in egg production. The reported percent of egg loss because of egg retention varies largely between streams. A high percent of egg retention in 2 streams was reported to be caused from the fish being harassed during spawning (Shepherd 1975). Spawning salmon potentially disturbed by cattle, to the degree that egg loss could occur, is a concern voiced in the guidelines of the Environmental Assessment for PACFISH (US Forest Service 1995). The ODFW conducted redd and carcass surveys of the study area each year. ODFW examined every carcass they found in 1996 and 1997. All of the salmon carcasses examined had fully spawned (ML Keefe, ODFW 1999, personal communication).
Table 5. Percentage of time spring chinook salmon spent on each activity in the presence of cattle visible to a human observer and in the absence of cattle, averaged over years. There were no significant differences between time spent on activities when cattle were present compared with when cattle were absent.

\begin{tabular}{lcc}
\hline Salmon Activity & $\begin{array}{r}\text { Cattle Present } \\
\% \text { of Time }\end{array}$ & $\begin{array}{c}\text { Cattle Absent } \\
\% \text { of Time }\end{array}$ \\
\hline Spawning & 0.90 & 0.66 \\
Working & 4.45 & 8.36 \\
Swimming Around Redd & 5.92 & 10.32 \\
Under Cover & 34.70 & 30.54 \\
Resting in Redd & 52.31 & 43.47 \\
Darting to Cover & 0.37 & 0.12 \\
Protecting the Redd & 0.30 & 0.19 \\
Absent From Redd & 1.13 & 6.41 \\
\hline
\end{tabular}

\section{CONCLUSION}

This riparian pasture was stocked near maximum levels for sustained cattle production and all livestock water was from the stream. Salmon spawning was not diminished by cattle grazing in the pasture during the spawning period. There was little interaction between the cattle and salmon during the 2 years of study.

Salmon behavior during the spawning season was similar each year. Salmon spent about half of their time resting in the redd and another third of their time under cover. Mating and the construction of egg pockets occurred soon after redd construction began, with the remainder of the spawning season spent protecting and working on the redd (fluffing), swimming around the redd, and sometimes actually leaving the area completely for a brief time.

Salmon did not react to the presence of cattle. The absence of egg retention, consistent salmon behavior with or without cows present, and the rarity of contact by cattle on redds indicated cattle presence had no measurable impact on the reproductive actions of adult spring chinook salmon.

This study was a case history of a typical riparian zone found on private land in northeastern Oregon. The meadow is larger than most of the riparian meadows adjacent to streams in the National Forest. The applicability of the results of this study to other riparian areas is unknown. We conducted the research with stocking densities and utilization levels that are similar to those of private lands in the area and much heavier than those on public lands. Because most of this research is related to specific interactions of cattle with salmon and their redds, use of the information in this case study in other areas should consider the grazing behavior of cattle. If cattle are not forced to spend time in the aquatic zone because of topography and availability of forage more than 3 meters from the creek, they would probably behave similarly to those in this case study. If topography, lack of usable forage, or other factors concentrate animals near the stream edge or in the stream for long periods, the conditions of the interactions of cattle and salmon could be different and the results would not be applicable. 


\section{LITERATURE CITED}

Anderson, E. W., M. M. Borman, and W. C. Krueger. 1998. The ecological province of Oregon. Corvallis, OR: Oregon Agricultural Experiment Station. Specia report 990. 138p.

ArnoLd, G. W. 1981. Grazing behavior. In: F. H. W. Morley [ed]. Grazing animals. New York, NY: Elsevier Scientific Publishing Co. p 79-104.

GILBERT, C. H. 1913. Age at maturity of the Pacific coast salmon of the genus Oncoryhnchus. Bulletin of the United States Bureau of Fisheries 32:1-22.

Kauffman, J. B., W. C. Krueger, and M. Vavra. 1985. Ecology and plant communities of the riparian area associated with Catherine Creek in northeastern Oregon. Corvallis, OR: Agricultural Experiment Station. Tech. bulletin. 147. $33 \mathrm{p}$.

Krueger, W. C. 1996. Grazing and ecosystem management. In: M. R. George [ed.]. Cattle management in grazed watersheds: A review of practices that protect water quality. Oakland, CA: UCD Animal Agriculture Research Center, UC Agriculture Issue Center. Publication 3381. 75 p.

Mclnnis, M. L. 1985. Ecological relationships among feral horses, cattle, and pronghorn in southeastern Oregon [dissertation]. Corvallis, OR: Oregon State University. $166 \mathrm{p}$.
Oregon Climate Service. 1998. Station No. 358746. Union, OR: Eastern Oregon Agricultural.

SHePHERD, B. 1975. Upper Skeena chinook stocks: evaluation of the Bear-Sustut, Morice, and lower Babine stocks. Vancouver, BC, Canada: Department of Environmental, Fisheries and Marine Service, Pacific Region, North Operations Branch. $41 \mathrm{p}$

Sneva, F. A. 1970. Behavior of yearling cattle on eastern Oregon range. Journal of Range Management 23:155-157.

US FoREST SERVICE. 1995. Environmental assessment for the interim strategies for managing anadromous fish-producing watersheds in eastern Oregon and Washington, Idaho and portions of California. Washington, DC: US Forest Service. $68 \mathrm{p}$.

US Geological Survey. 1996. Water resources data for Oregon: surface water records for eastern Oregon. Volume 1. Portland, OR: US Geological Survey.

US Geological Survey. 1997. Water resources data for Oregon: surface water records for eastern Oregon. Volume 1. Portland, OR: US Geological Survey.

Wagnon, K. A. 1963. Behavior of beef cows on a California range. Davis, CA: California Agricultural Experiment Station Bulletin 799. 58 p. 